\title{
Analisis Potensi Hutan Rakyat dalam Mendukung Kabupaten Kuningan sebagai Kabupaten Konservasi
}

\author{
Potential Analysis of Community Forests in Supporting Kuningan Regency \\ as a Conservation Regency
}

\begin{abstract}
Nana Rusyana ${ }^{1 *}$, Kukuh Murtilaksono ${ }^{2}$ \& Omo Rusdiana ${ }^{3}$
${ }^{1}$ Program Studi Ilmu Perencanaan Wilayah, Sekolah Pascasarjana, Institut Pertanian Bogor, Jalan Meranti Kampus IPB Dramaga Bogor 16680, Indonesia ; ${ }^{2}$ Departemen Ilmu Tanah dan Sumber Daya Lahan, Institut Pertanian Bogor, Jalan Meranti Kampus IPB Dramaga Bogor 16680, Indonesia; ${ }^{3}$ Departemen Silvikultur, Institut Pertanian Bogor, Jalan Lingkar Akademik Kampus IPB Kampus IPB Dramaga, Bogor 16680, Indonesia; "Penulis korespondensi. e-mail: nanaru@gmail.com
\end{abstract}

(Diterima: 15 Januari 2020; Disetujui: 13 Maret 2020)

\begin{abstract}
Kuningan Regency, as one of the conservation regencies in Indonesia, has not been able to produce timber on a large scale because its forest area is dominated by conservation and limited production forest. This has caused the production of timber from the forest area in Kuningan Regency not been able to fulfill market demands. As a result, timber from community forests became an alternative to fulfill those demands. Community forest is forest that grows on land that is burdened with ownership rights of minimum 0.25 ha and canopy cover of minimum 50\%, and/or having at least 500 stems/ha in the first year. As the demand for community timber increases, in the long term, the community forest management needs good planning to support the conservation regency policy. Therefore, objectives of this research are (1) to identify the types of community forest timber based on farmers' preferences and the financial feasibility, (2) to analyze land suitability and availability, (3) to analyze the leading commodity, and (4) to suggest the direction of the development regions. Methods of this research are AHP and TOPSIS, financial feasibility calculation (IRR, BC Ratio, NPV), land suitability analysis with matching criteria as well as GIS analysis, LQ, and SSA, together with descriptive analysis. Results showed that the leading types of timber were sengon, mahogany, africa, and teak. All were feasible to be cultivated with the recommended pattern, which was agroforestry. There are 12 districts with community forests as their leading sector, namely Ciawigebang, Cigandamekar, Cimahi, Cipicung, Ciwaru, Darma, Garawangi, Japara, Kramatmulya, Lebakwangi, Luragung, and Nusaherang district. The suggestion for direction of the development regions by type is for the north and east regions to be prioritized for sengon, teak, and africa, while the west and south regions to be prioritized for mahogany.
\end{abstract}

Keywords: community forest, conservation regency, development priority

\begin{abstract}
ABSTRAK
Kabupaten Kuningan, sebagai salah satu kabupaten konservasi di Indonesia, tidak dapat memproduksi kayu dalam skala besar karena sebagian besar kawasan hutannya merupakan hutan konservasi dan hutan produksi terbatas. Hal itu menyebabkan produksi kayu dari kawasan hutan Kabupaten Kuningan belum mampu memenuhi permintaan pasar. Akibatnya, kayu dari hutan rakyat menjadi alternatif untuk memenuhi permintaan tersebut. Hutan rakyat merupakan hutan
\end{abstract}


yang tumbuh di atas tanah yang dibebani hak milik dengan ketentuan minimal 0.25 ha dan penutupan tajuk tanaman kayu-kayuan minimal 50\%, dan atau pada tahun pertama jumlah batang minimal 500 batang/ha. Seiring semakin meningkatnya permintaan kayu rakyat, maka dalam jangka panjang pengelolaan hutan rakyat memerlukan perencanaan yang baik untuk mendukung kebijakan kabupaten konservasi. Untuk itu, penelitian ini bertujuan (1) mengidentifikasi jenis-jenis kayu hutan rakyat berdasarkan preferensi petani dan kelayakan finansial, (2) menganalisis kesesuaian dan ketersediaan lahan, (3) menganalisis komoditas unggulan, dan (4) membuat arahan wilayah pengembangan. Metode yang digunakan penelitian ini adalah AHP dan TOPSIS, perhitungan kelayakan finansial (IRR, BC Ratio, NPV), analisis kesesuaian lahan dengan metode pencocokan kriteria dan analisis SIG, LQ dan SSA, serta analisis deskriptif. Hasil penelitian menunjukkan bahwa jenis kayu unggulan adalah Sengon, Mahoni, Afrika, dan Jati. Keempat jenis kayu tersebut secara finansial layak untuk dibudidayakan dengan pola yang direkomendasikan yakni agroforestri. Terdapat 12 kecamatan yang mempunyai sektor unggulan pada hutan rakyat yaitu Ciawigebang, Cigandamekar, Cimahi, Cipicung, Ciwaru, Darma, Garawangi, Japara, Kramatmulya, Lebakwangi, Luragung, dan Nusaherang. Arahan wilayah pengembangan berdasarkan jenis adalah di wilayah utara dan timur diprioritaskan untuk sengon, jati, dan afrika, sementara wilayah barat dan selatan diprioritaskan untuk mahoni.

Kata kunci: hutan rakyat, kabupaten konservasi, wilayah pengembangan

\section{PENDAHULUAN}

Hutan alam adalah hutan yang terjadi secara alami tanpa campur tangan manusia, memiliki berbagai jenis pohon campuran dan dari segala umur. Sedangkan hutan tanaman adalah hutan yang sengaja ditanami dengan tanaman dengan tipe sejenis dengan tujuan menjadi sebuah hutan yang secara khusus dapat dieksploitasi tanpa membebani hutan alam, contohnya adalah Hutan Tanaman Industri (HTI). Saat ini kebutuhan kayu nasional mencapai 57.1 juta $\mathrm{m}^{3}$ per tahun dan hanya dapat dipenuhi oleh hutan alam dan hutan tanaman sebesar 45.8 juta $\mathrm{m}^{3}$ per tahun. Kondisi tersebut menyebabkan defisit kebutuhan kayu sebesar 11.3 juta $\mathrm{m}^{3}$ per tahun (Supriatna, 2011). Dampaknya konsumen beralih pada kayu hutan rakyat untuk memenuhi kebutuhan kayu sebagai bahan baku struktural (Apriliana, 2012), sehingga pengembangan hutan rakyat merupakan salah satu solusi pemenuhan kebutuhan kayu masyarakat saat ini.

Menurut SK Menhut No.49/kpts-II/1997 hutan rakyat didefinisikan sebagai hutan yang tumbuh di atas tanah yang dibebani hak milik dengan ketentuan minimal 0.25 ha dan penutupan tajuk tanaman kayu-kayuan minimal $50 \%$ dan atau pada tahun pertama jumlah batang minimal 500 batang/ha. Potensi hutan rakyat di Jawa Barat salah satunya terdapat di Kabupaten Kuningan, yang merupakan penghasil kayu rakyat terbanyak di wilayah Cirebon Raya dan peringkat ke 5 di Provinsi Jawa Barat (Dishut Jabar, 2018). Sementara itu, Kabupaten Kuningan juga merupakan kabupaten konservasi yang dideklarasikan tahun 2006 (Bappeda Kuningan, 2012), yaitu suatu kabupaten yang mempunyai kawasan konservasi ataupun kawasan yang berfungsi konservasi, berorientasi pada kebijakan pemanfaatan ruang dan lahan yang sesuai dengan peruntukan dan daya dukungnya, sehingga kelestarian sumberdaya hutan sebagai fungsi lindung lebih dapat dihargai. Alokasi lahan bagi kebutuhan investasi seperti untuk perkebunan dan pertambangan ditetapkan berdasarkan RTRWK yang sudah diperdakan serta disesuaikan dengan kondisi hutan yang ada (CIFOR, 2007). Kabupaten Konservasi juga bisa diartikan sebagai sebuah tata kelola pemerintahan adaptif yang melaksanakan pembangunan bertumpu pada upaya konservasi aspek sosial-budaya, ekonomi dan ekologi (Fatem et al., 2019). Prinsip kehati-hatian 
menjadi prioritas utama sebuah kabupaten konservasi dalam pemanfaatan potensi sumber daya alam termasuk komoditas hutan, sehingga eksploitasi tidak dilakukan secara tidak terkendali.

Kebijakan Kabupaten Konservasi juga tidak lepas dari kondisi wilayah Kabupaten Kuningan yang sebagian besar bertopografi perbukitan, curam dan rawan bencana gerakan tanah terutama di musim hujan, sehingga perlu adanya suatu kehati-hatian dalam pemanfaatan lahannya. Faktor lainnya yaitu keberadaan Taman Nasional Gunung Ciremai (TNGC) sebagai hulu DAS Cisanggarung sangat vital, tidak hanya sebagai sumber air bagi Kabupaten Kuningan, namun juga bagi kabupaten sekitarnya seperti Kabupaten dan Kota Cirebon, Kabupaten Indaramayu dan bahkan Kabupaten Brebes di Jawa Tengah. Selain sumber mata airnya, kawasan TNGC menyimpan kekayaan alam yang berlimpah seperti bahan galian tambang, tanah subur, serta berfungsi pula sebagai kawasan konservasi alam dan zona resapan air (Rismunandar et al., 2017).

Walaupun sebagian besar lahannya mempunyai keterbatasan biofisik dan rawan bencana, pemerintah Kabupaten Kuningan tetap menjadikan pengembangan hutan rakyat sebagai strategi implementasi kabupaten konservasi (Bappeda Kuningan, 2012). Hal ini karena kegiatan hutan rakyat pada dasarnya merupakan budaya masyarakat perdesaan dan sektor penting yang mendukung peningkatan ekonomi masyarakat. Sejak lama secara turun menurun petani secara mandiri mengembangkan hutan rakyat sebagai salah satu sumber pangan dan sumber pendapatan (Apriyanto et al., 2016). Hutan rakyat juga turut menjaga kelestarian lingkungan pada wilayah yang rentan bencana alam khususnya gerakan tanah. Hutan rakyat berkontribusi dalam memperbaiki lingkungan yang semula kritis dan tandus kini menjadi kawasan yang hijau dan subur (Widarti, 2015).

Penelitian ini bermaksud untuk mengidentifikasi potensi pengembangan hutan rakyat dalam mendukung kebijakan kabupaten konservasi melalui empat tujuan yaitu;

1) Mengidentifikasi jenis tanaman hutan rakyat yang berpotensi untuk dikembangkan dan layak untuk diusahakan berdasarkan preferensi masyarakat;

2) Memetakan kesesuaian jenis tanaman berdasarkan karakteristik lahan serta potensi ketersediaan lahan yang sesuai untuk pengembangan hutan rakyat;

3) Menentukan wilayah-wilayah prioritas pengembangan hutan rakyat berdasarkan komoditas unggulan.

4) Membuat arahan wilayah pengembangan untuk hutan rakyat.

\section{METODOLOGI}

Penelitian dilakukan di Kabupaten Kuningan, Provinsi Jawa Barat yang secara geografis terletak di antara $108^{\circ} 23^{\prime} 00^{\prime \prime}-$ $108^{\circ} 47^{\prime} 00^{\prime}$ BT dan 6 6 $47^{\prime} 00^{\prime \prime}-7^{\circ} 12^{\prime} 00^{\prime}$ LS, dengan luas wilayah $1,195.71 \mathrm{~km}^{2}$, terdiri dari 32 kecamatan. Penelitian dilakukan dari bulan Mei 2018-Juli 2019 dan observasi lapang dilakukan antara bulan Februari-Mei 2019.

Data yang digunakan dalam penelitian terdiri atas data primer dan sekunder. Pengumpulan data primer dilakukan guna melengkapi data sekunder yang tersedia. Data primer diperoleh dari hasil wawancara responden dalam penentuan jenis tanaman prioritas dan kelayakan finansial, sedangkan data sekunder berupa meliputi: (1) Data luas hutan rakyat Tahun 2011-2016 (BPS); (2) Data produksi hutan rakyat tahun 2011 - 2017 (BPS); (3) Satuan Peta Tanah/SPT (BBSDLP); (4) Peta Curah Hujan; (5) Penggunaan lahan; (6) Peta Pola Ruang (BAPPEDA Litbang); (7) Perwilayahan jumlah bulan kering (peta Land System)

Alat analisis yang digunakan yaitu software pengolah data (Excel dan Expert Choice). Sedangkan untuk pengolahan data spasial atau peta menggunakan software ArcGIS.

\section{Identifikasi Jenis Tanaman Prioritas}


Untuk memperoleh preferensi petani mengenai jenis komoditas yang ingin ditanam, yang juga bisa memberikan manfaat ekologi, ekonomi, dan sosial, digunakan metode AHP dan TOPSIS. Penentuan jenis kayu yang akan ditanam di hutan rakyat mempertimbangkan banyak faktor. Salah satu metode yang lazim digunakan dalam pembuatan keputusan dengan multi kriteria adalah menggunakan pendekatan kuantitatif gabungan AHP dan TOPSIS, dari hasil wawancara terhadap responden. Menurut Borza et al. (2019) metode kuantitatif telah dianggap sebagai metode yang menguntungkan karena dapat membandingkan berbagai alternatif pada sebuah proyek. Proses hierarki analitis (AHP) dan teknik untuk mengurutkan preferensi berdasarkan kemiripan terhadap solusi ideal (TOPSIS) dapat digunakan dengan baik untuk mengevaluasi berbagai faktor terlibat dalam proses lingkungan.

Jenis tanaman prioritas yang akan dijadikan sebagai alternatif dilihat dari data produksi kayu rakyat Kabupaten Kuningan tahun 2011-2017, studi literatur dan wawancara responden. Kriteria tanaman yaitu faktor-faktor yang menjadi pertimbangan petani dalam pemilihan jenis tanaman hutan rakyat, diperoleh dari studi literatur dan wawancara responden.

Pemangku kepentingan dalam pengelolaan hutan rakyat beragam, masingmasing mempunyai motivasi, peran, dan tujuan yang beragam (Foncha \& Ewule, 2020). Secara umum pemangku kepentingan hutan rakyat di Kabupaten Kuningan dikategorikan menjadi empat yaitu petani, industri, Lembaga Swadaya Masyarakat (LSM) dan pemerintah.

Responden ditentukan menggunakan metode purposive sampling. Jumlah total sampel adalah 30 orang, yang sebagian besar (90\%) adalah petani penggarap, kemudian pedagang kayu/tengkulak (industri), pemerintah, dan LSM. Pengambilan contoh responden menggunakan metode pengambilan sampel tiga tingkat (three stage sampling).

Pada satuan sampling tingkat pertama, dipilih kecamatan yang tersebar mewakili masing-masing wilayah barat, timur, tengahutara, dan selatan. Untuk wilayah barat dipilih dari Kecamatan Cilimus, wilayah timur dari Kecamatan Cibingbin, wilayah Selatan yaitu dari Kecamatan Cilebak, dan wilayah tengahutara dari Kecamatan Japara dan Karamatmulya.

Pada satuan sampling tingkat kedua yaitu domisili desa responden, dipilih desa yang mewakili kecamatan dengan kriteria terdapat hutan rakyat. Untuk wilayah barat dipilih dari Desa Cibeureum dan Sampora di Kecamatan Cilimus, wilayah timur dari Desa Cipondok dan Ciangir di Kecamatan Cibingbin. Wilayah Selatan dari Desa Mandapajaya dan Legokherang di Kecamatan Cilebak. Terakhir untuk wilayah tengah-utara dari Desa Dukuh Dalem di Kecamatan Japara dan Desa Pajambon di Kecamatan Karamatmulya.

Terakhir pada satuan sampling tingkat ketiga dipilih petani dengan jumlah responden masing-masing 7 orang di wilayah barat dan tengah-utara, serta masing-masing 8 orang di wilayah selatan dan timur.

Tahap pertama yaitu menggunakan metode Analytical Hierarchy Process atau AHP yang dikembangkan oleh Prof. Thomas Lorie Saaty dari Wharton Business School di awal tahun 1970 (Purnomo et al., 2013). Pada AHP diberikan pembobotan perbandingan (pairwaise comparison) setiap kriteria terhadap jenis kayu menggunakan software Expert Choice. Jika matriks perbandingan keputusan konsisten yaitu Consistency Ratio (CR) < 0.1, pendapat para pakar (responden) akan diolah kembali untuk diberi pembobotan penentuan alternatif dalam hal ini jenis kayu, kemudian ditetapkan nilai eigenvector rata-rata. Struktur analisis AHP bisa dilihat pada Gambar 1. 


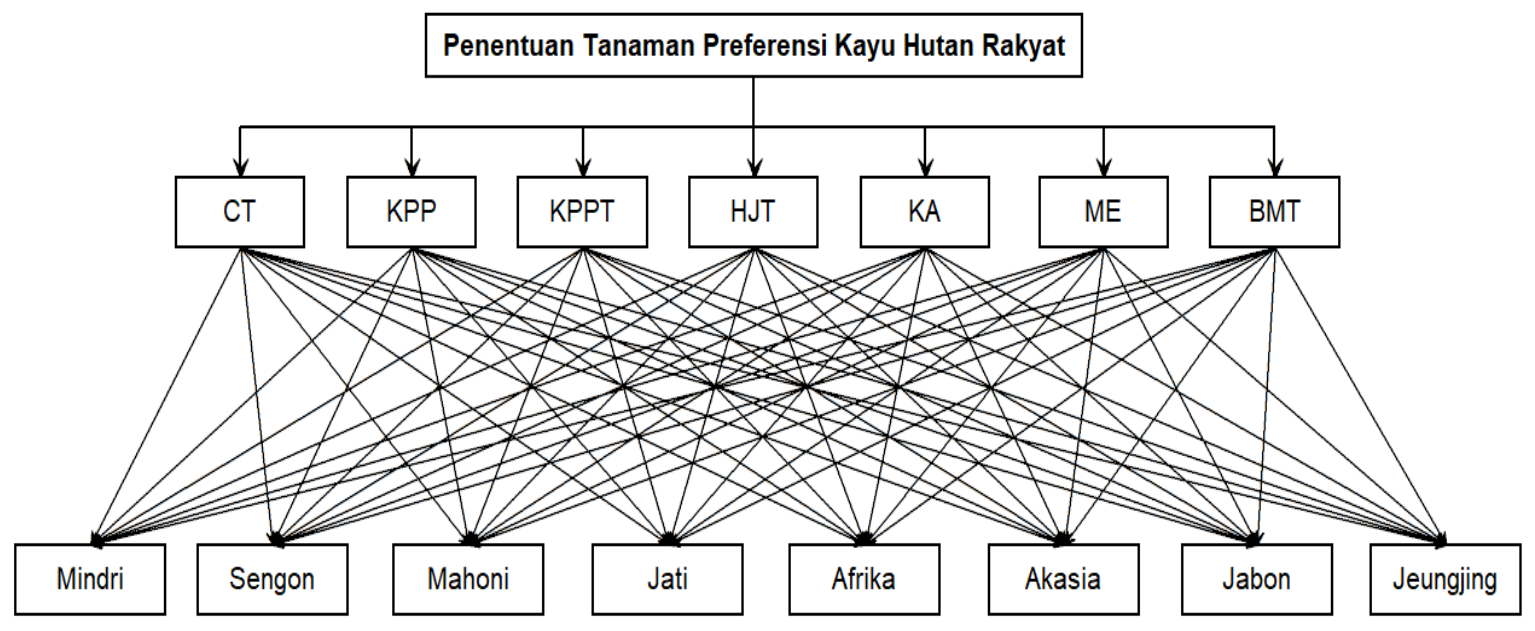

Keterangan:

CT (Cepat Tumbuh), KPP (Kemudahan dalam penanaman dan pemeliharaan), KPPT (Kemudahan pemasaran dan permintaan pasar yang tinggi), HJT (Harga jual tinggi), KA (Kesesuaian Agroklimat), ME (Memberikan manfaat ekologi yaitu mampu memperbaiki kondisi lahan), BMT (Bibit mudah di dapat dan harganya terjangkau).

Gambar 1. Struktur hierarki AHP dalam pemilihan jenis tanaman kayu preferensi hutan rakyat di Kabupaten Kuningan

Tahap kedua adalah penentuan susunan alternatif dengan menggunakan metode Technique for Order of Preference by Similarity to Ideal Solution atau TOPSIS, yang diperkenalkan pertama kali oleh Yoon dan Hwang (Purnomo et al., 2013). Pada TOPSIS bobot yang didapat pada metode AHP dikalikan dengan matriks data alternatif yang telah dinormalisasi, untuk kemudian dihitung nilai solusi ideal positif dan negatif dari masing-masing alternatif. Hasil TOPSIS berupa susunan alternatif secara hierarki dari nilai jenis tanaman kayu yang berjarak terpendek terhadap solusi ideal positif dan berjarak terjauh dengan solusi ideal negatif. Pengurutan dilakukan mulai dari alternatif terbaik hingga terburuk berdasarkan nilai preferensi nya, dan jenis tanaman prioritas akan ditentukan 3 besar dari hasil TOPSIS.

\section{Analisis Finansial Kelayakan Pengusahaan Hutan Rakyat}

Analisis kelayakan finansial digunakan agar risiko kegagalan usaha terutama mengenai finansial dapat diminimalisir sehingga usaha dapat berjalan lancar dan semakin berkembang, sekaligus mendapatkan keuntungan yang optimal (Fatmawati et al., 2018). Dalam pengembangan hutan rakyat, analisis kelayakan finansial digunakan sebagai instrumen yang akan membantu petani untuk memilih komposisi jenis yang sebaiknya dikembangkan dan menentukan daur yang paling menguntungkan melalui berbagai pilihan (Setiawan et al., 2014). Analisis finansial yang digunakan sebagai berikut:

1) Net Present Value (NPV), digunakan untuk menghitung nilai sekarang dari laba suatu investasi tersebut yang memberi keuntungan atau bahkan sebaliknya.

2) Internal Rate of Return (IRR), menghitung tingkat bunga pada saat arus kas sama dengan nol atau pada saat laba (pendapatan dikurangi laba) yang telah di-discount factor sama dengan nol.

3) Benefit Cost Ratio (BCR) atau Gross B/C, adalah rasio dari pendapatan $(\mathrm{B}=$ Benefit) dibandingkan dengan biaya $(\mathrm{C}=\mathrm{Cost})$ yang dihitung nilai sekarang (faktor telah diberi pengurangan).

\section{Identifikasi Kesesuaian Lahan untuk Pengembangan Hutan Rakyat}

Analisis kesesuaian lahan dilakukan menggunakan metode FAO (1976) yaitu membandingkan antara karakteristik lahan dengan persyaratan tumbuh komoditas tanaman. Hal tersebut dilakukan menggunakan 
bantuan teknologi Sistem Informasi Geografis atau SIG. Teknologi SIG sangat membantu dalam penyusunan rencana yang berbasis spasial. Salah satu manfaatnya dapat digunakan untuk analisis kesesuaian penggunaan lahan untuk menentukan lokasi lahan-lahan yang sesuai untuk digunakan bagi pengelolaan hutan oleh rakyat (Herwirawan et al., 2019).

Data Satuan Peta Tanah (SPT), iklim yaitu peta curah hujan dan bulan kering dioverlay dan di-query pada software Sistem Informasi Geografis (SIG) yaitu ArcGIS. Metode Query kemudian dilakukan untuk menentukan kriteria dari hasil penggabungan penilaian kecocokan (matching) dengan persyaratan tanaman berdasarkan Ritung et al. (2011) untuk Sengon, Mahoni, Jati. Untuk Afrika berdasarkan NAS (1983) dan Buharman et al. (2011). Hasilnya berupa peta kelas kesesuaian lahan dari masing-masing tanaman preferensi pada tingkat kelas. Penentuan kelas pada proses overlay berdasarkan faktor pembatas terberat. Kelas kesesuaian tersebut adalah (1) S1 (Sangat Sesuai), (2) S2 (Cukup Sesuai), (3) S3 (Sesuai Marjinal) dan, (4) N (Tidak Sesuai).

Diagram alir penentuan kesesuaian lahan untuk komoditas hutan rakyat terpilih disajikan pada Gambar 2.

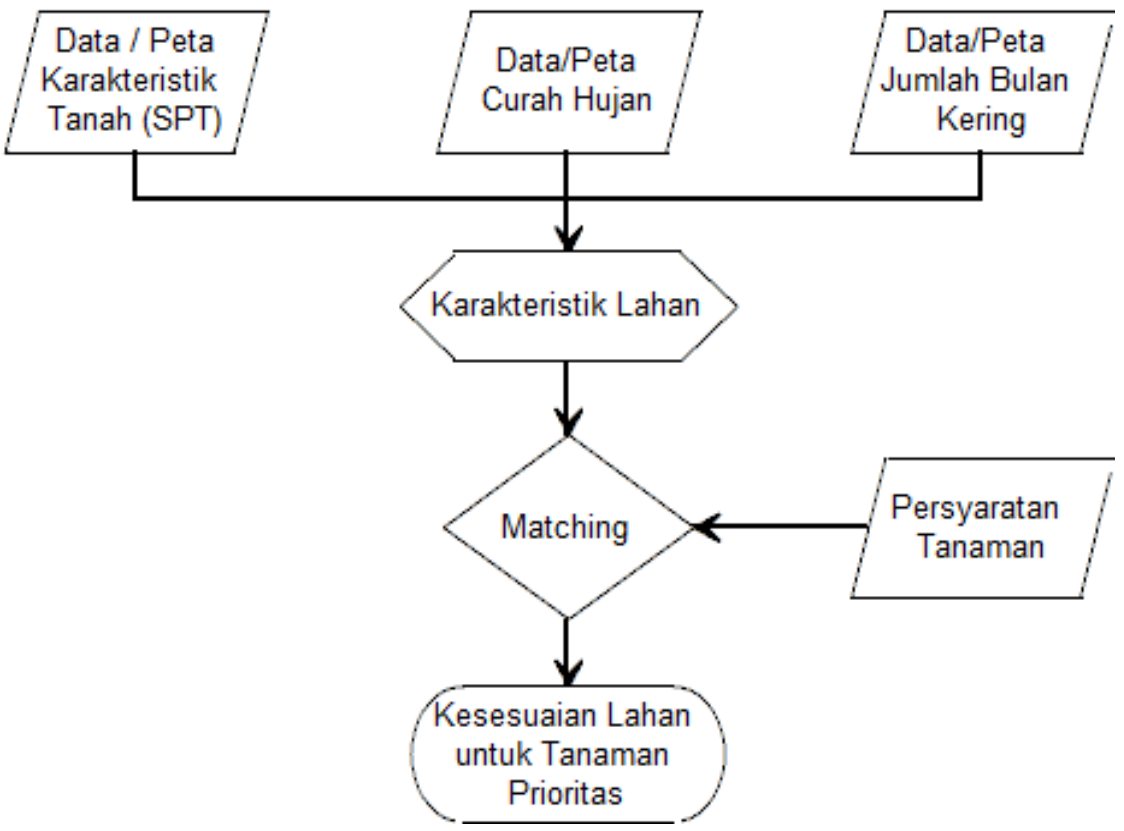

Gambar 2. Diagram alir penentuan kesesuaian lahan untuk tanaman preferensi hutan rakyat di Kabupaten Kuningan

\section{Identifikasi Ketersediaan Lahan untuk Pengembangan Hutan Rakyat}

Sumberdaya lahan merupakan faktor yang sangat penting dalam usaha hutan rakyat. Keberadaan dan ketersediaan lahan dalam kuantitas dan kualitas menjadi faktor utama dibangunnya hutan rakyat (Rochmayanto \& Supriadi, 2012). Untuk analisis identifikasi ketersediaan lahan bagi pengembangan hutan rakyat didasarkan atas 2 aspek, yang pertama adalah penggunaan lahan saat ini dan yang kedua adalah alokasi ruang atau pola ruang berdasarkan Rencana Tata Ruang Wilayah Kabupaten (RTRWK).

Untuk penggunaan lahan, penentuan lokasi yang tersedia didasarkan pada kriteria sebagai berikut: (1) Lahan yang bukan merupakan pertanian lahan basah dalam hal ini sawah, (2) Lahan bukan permukiman, (3) Lahan bukan tubuh air, (4) Lahan-lahan kering lainnya terutama yang tidak bervegetasi hutan seperti semak belukar, tegalan/ladang, rumput/padang rumput, kebun campuran, dan lain-lain. 
Untuk pola ruang, kriteria yang digunakan adalah: (1) Merupakan kawasan budi daya pertanian lahan kering (lahan non sawah, peternakan, dan perikanan), (2) Di luar kawasan hutan (hutan produksi, hutan konservasi, hutan lindung), (3) Tidak masuk kawasan perkebunan negara, (4) Di luar kawasan pemukiman, (5) Tidak ditetapkan sebagai zona khusus.

Selain itu ditentukan lokasi-lokasi lahan prioritas untuk pengembangan hutan rakyat dengan kriteria (Dirgantara, 2008): (1) Lahan kering dengan kemiringan lahan di atas 25\%, (2) Lahan-lahan disekitar tubuh air (sungai, danau, mata air), (3) Lahan rawan bencana khususnya gerakan tanah dan banjir, dan (4)
Lahan yang ditetapkan sebagai kawasan perlindungan.

Analisis ketersediaan lahan hutan rakyat dilakukan dengan menggunakan metode overlay dan logical query pada software ArcGIS, dengan tahapan sebagai berikut: (1) Overlay antara Peta Penggunaan Lahan, Peta Pola Ruang, Peta Kawasan Hutan, dan Peta Administrasi, (2) Melakukan analisis logical query sesuai dengan kriteria ketersediaan dari segi penggunaan lahan dan pola ruang, (3) Hasil akhir berupa peta ketersediaan lahan untuk pengembangan hutan rakyat di setiap kecamatan. Diagram alir untuk analisis ketersediaan lahan bisa dilihat pada Gambar 3.

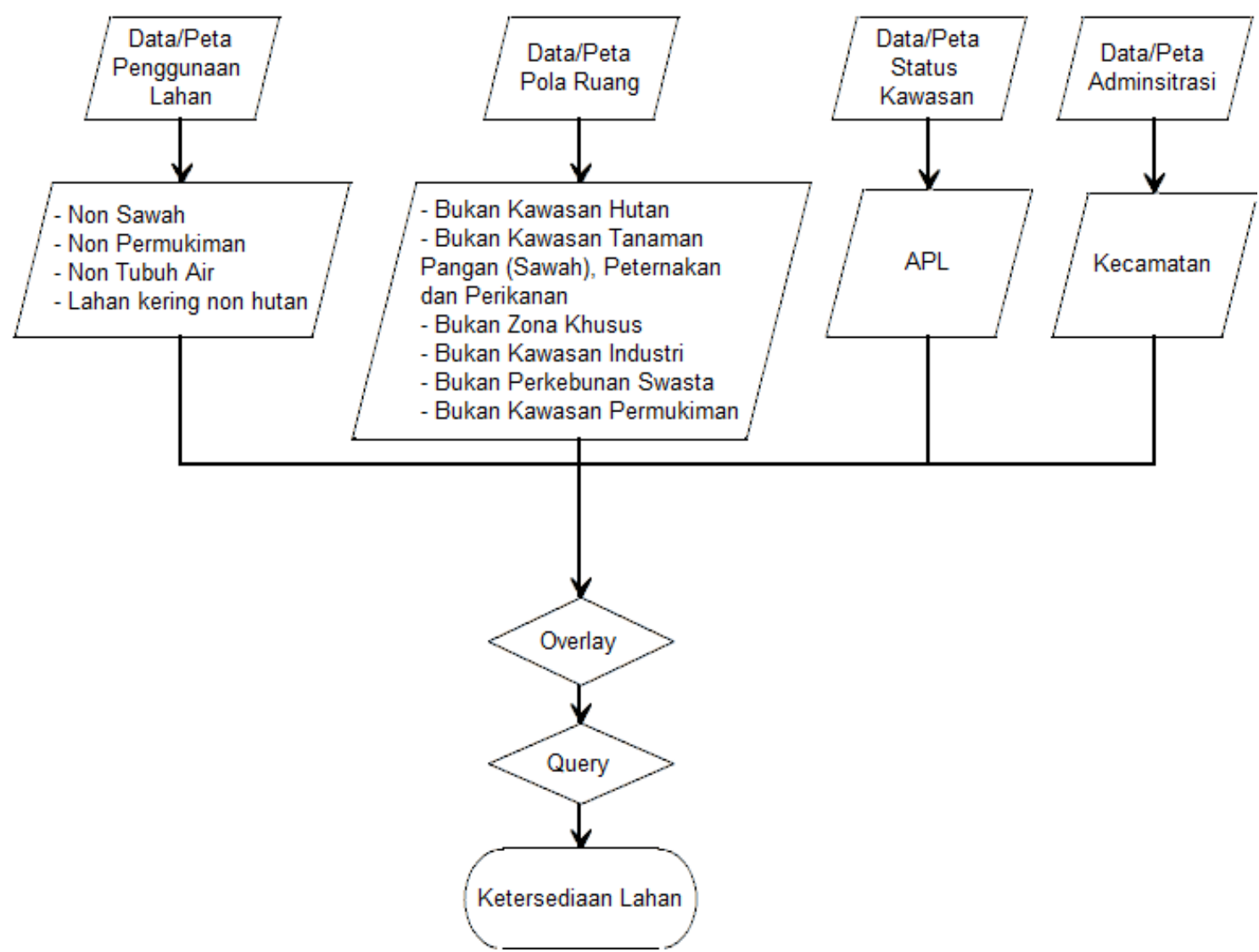

Gambar 3. Diagram alir analisis ketersediaan lahan untuk hutan rakyat di Kabupaten Kuningan

\section{Identifikasi Lahan Sesuai dan Tersedia untuk Pengembangan Hutan Rakyat}

Selanjutnya peta kesesuaian lahan untuk jenis tanaman preferensi di-overlay kembali dengan peta ketersediaan lahan di software ArcGIS. Logical query kembali dilakukan agar mendapatkan lokasi lahan-lahan sesuai dan tersedia untuk setiap jenis tanaman prioritas hutan rakyat di Kabupaten Kuningan.

\section{Penentuan Komoditas Unggulan}

Dalam kaitannya dengan pengembangan wilayah, penting untuk mengidentifikasi komoditas unggulan. Informasi komoditas 
unggulan digunakan sebagai dasar pertimbangan dalam menentukan strategi pengembangan wilayah dengan berdasarkan keterkaitan antara perkembangan kondisi sosial ekonomi masyarakat, potensi sumberdaya alam, serta ketersediaan sarana dan prasarana wilayah dalam mendukung aktivitas perekonomian di wilayah tersebut (Cipta et al., 2017).

Untuk mengetahui bagaimana dan seberapa besar kinerja pengembangan hutan rakyat pada kegiatan pengembangan wilayah di Kabupaten Kuningan selama ini, maka akan dilakukan analisis Location Quotient (LQ) dan Shift Share Analysis (SSA) dengan tujuan untuk melihat sebaran komoditas unggulan hutan rakyat dan sektor lainnya. Data yang akan digunakan adalah data luas pemanfaatan lahan kering di setiap kecamatan tahun 2011 dan 2016 yang bersumber dari BPS.

\section{Location Quotient (LQ)}

Rustiadi et al. (2009) mengemukakan untuk mengetahui potensi aktivitas ekonomi yang merupakan indikator sektor basis dan non-basis dapat digunakan metode Location Quotient atau LQ. Menurut Tarigan (2005), jika LQ menunjukkan angka lebih dari satu (LQ > 1) berarti sektor tersebut merupakan sektor basis, dengan kata lain sektor tersebut berpotensi ekspor ke daerah lain. Kemudian

jika angka LQ kurang dari satu (LQ $<1)$ berarti sektor tersebut bukan merupakan sektor basis, dengan kata lain sektor tersebut tidak berpotensi untuk ekspor ke daerah lain. Nilai LQ dihitung dengan rumus:

$$
L Q_{i j}=\frac{X_{i j} / X_{i}}{X_{j} / X_{m}}
$$

Dimana:

$L Q_{\mathrm{ij}} \quad=$ Indeks pemusatan aktivitas ke-j di wilayah ke-i

$\mathrm{X}_{\mathrm{ij}} \quad=$ Derajat aktivitas ke-j di wilayah ke-i

$\mathrm{X}_{\mathrm{i}} \quad=$ Total aktivitas di wilayah ke-i

$\mathrm{X}_{\mathrm{j}} \quad=$ Total aktivitas ke-j di semua wilayah

$\mathrm{X}$. = derajat aktivitas total seluruh wilayah
Walaupun demikian LQ memiliki beberapa kelemahan, antara lain merupakan indikator kasar yang deskriptif, merupakan kesimpulan sementara dan tidak memperhatikan struktur ekonomi setiap daerah. Mengingat bahwa hasil produksi dan produktivitas tenaga kerja di setiap daerah adalah berbeda, juga adanya perbedaan sumber daya yang bisa dikembangkan di setiap daerah (Zaenuri, 2015).

\section{Shift Share Analysis (SSA)}

Rustiadi et al. (2009) mengemukakan untuk melihat potensi pertumbuhan sektoral dari suatu kawasan/wilayah, dapat digunakan analisis Shift Share. Indikator yang digunakan untuk menunjukkan potensi ekonomi dalam analisis Shift Share adalah sebagai berikut:

Total Shift (pergeseran keseluruhan), adalah pergeseran total suatu industri i adalah sama dengan selisih antara pertumbuhan yang terjadi (actual change) dengan pertumbuhan/perubahan yang diharapkan (expected change) terjadi jika industri i tumbuh pada laju yang sama dengan laju total pertumbuhan nasional (semua industri). Proportional Shift, adaah pergeseran yang diamati tergantung pada perbedaan antara laju pertumbuhan nasional (dari seluruh industri) dengan laju pertumbuhan nasional dari masingmasing industri i. Differential Shift, adalah pergeseran yang diamati tergantung pada perbedaan antara laju pertumbuhan industri di wilayah bersangkutan dengan laju pertumbuhan industri di tingkat lebih tinggi.

Persamaan analisis Shift Share adalah:

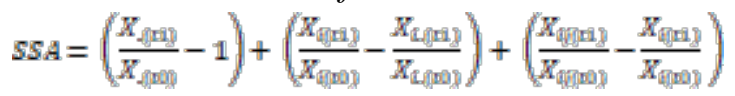

(b)

(c)

Dimana:

(a) = komponen share

(b) = komponen proportional shift

(c) = komponen differential shift

$\mathrm{X}=$ Nilai total aktifitas dalam total wilayah

$\mathrm{X}_{\mathrm{i}} \quad=$ Nilai total aktifitas tertentu dalam total wilayah 


$$
\begin{aligned}
\mathrm{X}_{\mathrm{ij}} & =\text { Nilai total aktifitas tertentu dalam } \\
& \quad \text { unit wilayah tertentu } \\
\mathrm{t} 1 & =\text { titik tahun akhir } \\
\mathrm{t} 0 & =\text { titik tahun awal }
\end{aligned}
$$

Hasil analisis LQ $>1$ dan Differential Shift positif selanjutnya dianalisis untuk mengetahui di mana saja kecamatan yang mempunyai sektor unggulan pada hutan rakyat. Hal itu akan menjadi salah satu acuan dalam membuat arahan perwilayahan pengembangan hutan rakyat di Kabupaten Kuningan.

\section{HASIL DAN PEMBAHASAN}

\section{Preferensi Tanaman Hutan Rakyat}

Berdasarkan hasil wawancara terdapat 7 kriteria yang biasa dijadikan sebagai pertimbangan oleh masyarakat dalam penanaman kayu [Tabel 1]. Delapan jenis kayu biasa dibudidayakan oleh masyarakat yaitu Sengon, Jeungjing, Mahoni, Jati, Akasia, Mindri, Afrika, dan Jabon.

Tabel 1. Hasil penentuan kriteria tanaman preferensi dengan AHP dalam pengelolaan hutan rakyat di Kabupaten Kuningan

\begin{tabular}{lll}
\hline No & Kriteria & Nilai Eigen Vector \\
\hline 1 & Memberikan manfaat ekologi yaitu mampu memperbaiki kondisi lahan & 0.195 \\
2 & Kemudahan dalam penanaman dan pemeliharaan & 0.182 \\
3 & Kemudahan pemasaran dan permintaan pasar yang tinggi & 0.150 \\
4 & Kesesuaian agroklimat & 0.149 \\
5 & Bibit mudah didapat dan harganya terjangkau & 0.137 \\
6 & Harga jual yang tinggi & 0.121 \\
7 & Cepat Tumbuh & 0.067 \\
& Jumlah & 1.000 \\
\hline
\end{tabular}

Hasil analisis kuesioner AHP oleh pakar menggunakan Expert Choice, diperoleh Consistency Ratio (CR) pakar sebesar 0.05 dari 30 orang responden. Berdasarkan 7 kriteria yang ditanyakan, kriteria dengan nilai Eigen Vector (EV) tertinggi adalah memberikan manfaat ekologi dan mampu memperbaiki kondisi lahan (0.194), sedangkan cepat tumbuh menjadi prioritas terendah (0.067), lihat Tabel 1.

Analisis perbandingan antara kriteria dan jenis kayu menunjukkan nilai Consistency Ratio (CR) 0.01. Berdasarkan nilai Eigen Vector, urutan jenis tanaman dari nilai tertinggi sampai terendah adalah Sengon, Mahoni, Afrika, Jati, Mindri, Akasia, Jeungjing, Jabon.

Selanjutnya hasil perhitungan TOPSIS di mana alternatif yang terpilih adalah yang memiliki jarak terpendek dari solusi ideal positif dan jarak terjauh dari solusi ideal negatif, menunjukkan urutan tertinggi Sengon dengan nilai 0.747 dan terendah adalah Jabon dengan nilai 0.079 [Tabel 2]. Empat jenis teratas berdasarkan TOPSIS adalah tanaman pereferensi, dan banyak dibudidayakan, maka tanaman preferensi dalam pengelolaan hutan rakyat adalah Sengon, Mahoni, Afrika, dan Jati.

Tabel 2. Urutan jenis tanaman kayu prioritas hasil perhitungan TOPSIS dalam pengelolaan hutan rakyat di Kabupaten Kuningan

\begin{tabular}{lllllll}
\hline \multirow{2}{*}{ No. } & Alternatif & $\begin{array}{l}\text { Nilai Solusi } \\
\text { Positif (SIP) }\end{array}$ & $\begin{array}{l}\text { Ideal } \\
\text { Nilai Solusi } \\
\text { Negatif (SIN) }\end{array}$ & $\begin{array}{l}\text { Ideal } \\
\text { Nilai } \\
\text { SIP + SIN }\end{array}$ & $\begin{array}{l}\text { Nilai } \\
\text { TOPSIS }\end{array}$ \\
\hline 1 & Sengon & 0.035 & 0.105 & 0.140 & 0.747 \\
2 & Mahoni & 0.067 & 0.066 & 0.133 & 0.498 \\
3 & Afrika & 0.082 & 0.033 & 0.115 & 0.285 \\
4 & Jati & 0.100 & 0.029 & 0.129 & 0.224 \\
5 & Mindri & 0.096 & 0.018 & 0.114 & 0.156 \\
6 & Akasia & 0.100 & 0.015 & 0.115 & 0.129 \\
7 & Jeungjing & 0.108 & 0.012 & 0.119 & 0.097 \\
8 & Jabon & 0.107 & 0.009 & 0.116 & 0.079 \\
\hline
\end{tabular}




\section{Analisis Kelayakan Pengusahaan Hutan Rakyat}

Luas lahan penduduk yang ditanami kayu berkisar dari $0.035-1$ ha. Rata-rata luas lahan yang diusahakan adalah 0.21 ha. Pola pengelolaan dominan adalah agroforestri yaitu mengkombinasikan tanaman kayu dengan tanaman pertanian lainnya, kecuali di wilayah timur yang dominan monokultur/polykultur. Komposisi kayu dominan yang ditanam adalah Sengon dan Mahoni, sedangkan di wilayah timur adalah Sengon dan Jati.

Daur tebang tanaman kurang diperhatikan, sebagian besar petani memanen kayu ketika butuh (daur butuh), sebagian menjual kayunya bahkan ketika umur tanaman masih belum ideal. Idealnya daur Sengon minimal 5 tahun (Nuroniah \& Putri, 2013), Mahoni minimal 10 tahun (Mindawati \& Megawati, 2013), Jati minimal 15 - 20 tahun (Tagfira et al., 2018). Semua responden menjual hasil kayu secara borongan kepada tengkulak.

Analisis kelayakan pada pola pengelolaan eksisting menggunakan asumsi luas rata-rata hutan rakyat sesuai Peraturan Menteri Kehutanan P.9/Menhut-II/2013 yaitu 0.25 ha. Untuk jarak tanam agroforestri 4 x $4 \mathrm{~m}$ atau monokultur $3 \times 3 \mathrm{~m}$, nilai suku bunga pada 7.5\% (KUR BRI) dan 12.5\% (Non KPR BRI) per 25 Juli 2019, serta komponen biaya pengusahaan lainnya secara rata-rata sesuai kondisi lapang, dengan masa pengelolaan 10 tahun.

Hasil analisis NPV, IRR, dan B/C R untuk pengusahaan pola eksisting menunjukan hutan rakyat layak untuk diusahakan di semua wilayah, baik secara agroforestri ataupun monokultur/polykultur (wilayah timur). Ini ditunjukan dengan nilai NPV $>0$, nilai IRR $>$ suku bunga, dan B/C Ratio > 1 pada semua skenario suku bunga [Tabel 3].

Tabel 3. Hasil perhitungan NPV, IRR, BCR pola pengelolaan hutan rakyat eksisting di Kabupaten Kuningan tahun 2019

\begin{tabular}{|c|c|c|c|c|c|}
\hline \multirow{2}{*}{ No } & & \multicolumn{4}{|l|}{ Wilayah } \\
\hline & & Barat & Timur & Tengah-Utara & Selatan \\
\hline 1 & Komposi kayu dominan & \multicolumn{4}{|l|}{ Sengon, } \\
\hline 2 & Pola pengelolaan dominan & Agroforestri & Monokultur & Agroforestri & Agroforestri \\
\hline \multirow[t]{4}{*}{3} & Suku bunga 7\% & & & & \\
\hline & NPV (Rp, x 1,000) & 8,744 & 19,451 & 8,744 & 6,579 \\
\hline & IRR & $23.94 \%$ & $29.62 \%$ & $20.74 \%$ & $23.94 \%$ \\
\hline & BCR & 3.1 & 4.6 & 3.1 & 2.7 \\
\hline \multirow[t]{4}{*}{4} & Suku bunga $12.5 \%$ & & & & \\
\hline & NPV (Rp, x 1,000) & 5,042 & 11,585 & 5,042 & 3,657 \\
\hline & IRR & $17.88 \%$ & $23.29 \%$ & $14.84 \%$ & $17.88 \%$ \\
\hline & BCR & 2.4 & 3.4 & 2.4 & 2.1 \\
\hline
\end{tabular}

Pada skenario pola monokultur untuk Sengon, Mahoni, Afrika, dan Jati, di mana daur tebang yang diasumsikan adalah 5 tahun untuk Sengon dan Afrika, dan 15 tahun untuk Mahoni dan Sengon. Hasil analisis menunjukan semua tanaman preferensi layak untuk diusahakan pada semua suku bunga, termasuk pada hasil uji sensitivitas, yaitu dimana diasumsikan harga kayu turun $10 \%$ dan biaya komponen pengelolaan naik 10\% (Ibrahim, 2017), seperti yang bisa dilihat pada Tabel 4 . 
Journal of Regional and Rural Development Planning (Jurnal Perencanaan Pembangunan Wilayah dan Perdesaan) Februari 2020, 4 (1): 14-30

Tabel 4. Nilai NPV, IRR, dan BCR komoditas Sengon, Mahoni, Afrika, dan Jati pada pola monokultur di berbagai skenario suku bunga dan hasil uji sensitivitasnya, dalam pengelolaan hutan rakyat di Kabupaten Kuningan tahun 2019

\begin{tabular}{|c|c|c|c|c|c|c|c|c|}
\hline \multirow{3}{*}{$\begin{array}{l}\text { Komponen } \\
\text { Kelayakan }\end{array}$} & \multicolumn{8}{|c|}{ Suku Bunga / Discount Factor } \\
\hline & \multicolumn{2}{|c|}{ Sengon } & \multicolumn{2}{|c|}{ Mahoni } & \multicolumn{2}{|l|}{ Afrika } & \multicolumn{2}{|l|}{ Jati } \\
\hline & $7 \%$ & $12,5 \%$ & $7 \%$ & $12,5 \%$ & $7 \%$ & $12,5 \%$ & $7 \%$ & $12,5 \%$ \\
\hline $\begin{array}{l}\text { NPV } \\
\text { (Rp. x 1,000) }\end{array}$ & 10,091 & 7,166 & 13,416 & 5,095 & 8,015 & 5,489 & 24,893 & 9,071 \\
\hline IRR & $33.9 \%$ & $27.3 \%$ & $12.9 \%$ & $7.3 \%$ & $28.1 \%$ & $21.9 \%$ & $12.3 \%$ & $6.8 \%$ \\
\hline BCR & 3.5 & 2.8 & 3.5 & 2.1 & 3.0 & 2.4 & 3.6 & 2.0 \\
\hline $\begin{array}{l}\text { Hasil uji } \\
\text { sensitivitas }\end{array}$ & & & & & & & & \\
\hline $\begin{array}{l}\text { NPV } \\
\text { (Rp. x 1,000) }\end{array}$ & 8,137 & 5,551 & 10,898 & 3,564 & 6,135 & 3,938 & 20,357 & 6,340 \\
\hline IRR & $27.4 \%$ & $21.2 \%$ & $10.5 \%$ & $5.1 \%$ & $21.7 \%$ & $15.8 \%$ & $10.1 \%$ & $4.7 \%$ \\
\hline BCR & 2.8 & 2.3 & 2.9 & 1.7 & 2.4 & 1.9 & 2.9 & 1.7 \\
\hline
\end{tabular}

Jika dilihat dari Payback Period nya pengusahaan kayu rakyat memerlukan waktu relatif lama, paling cepat misalnya untuk jenis Sengon yaitu pada umur 3-5 tahun. Ini menunjukan bahwa pola Agroforestri bisa lebih memberikan pendapatan jangka pendek atau lebih cepat untuk petani melalui tanaman semusim atau tahunan, tanaman kayu bisa dipanen untuk memenuhi keperluan jangka panjang atau ketika ada kebutuhan mendesak.

Hutan rakyat yang dikembangkan dengan pola agroforestri akan memberikan hasil tidak hanya kayu saja melainkan juga buah-buahan, pangan, obat-obatan, bambu, tanaman industri dan lain sebagainya, ini semua tergabung dalam kelompok hasil hutan bukan kayu (HHBK) (Diniyati \& Achmad, 2015). Peran tanaman bukan kayu pada hutan rakyat juga sangat besar dalam mempertahankan eksistensi dan mendorong perkembangan usaha hutan rakyat terutama di wilayah-wilayah di mana pemilikan lahan oleh petani sangat sempit (Irawanti et al., 2012).

Hal ini juga didasari bahwa tidak semua hasil kayu (jenis kayu) yang biasa dibudidayakan oleh petani di hutan rakyat bernilai ekonomi baik. Berdasarkan wawancara di lapangan, jenis kayu Sengon dan Jati adalah komoditas yang paling sering diserap pasar, berpotensi diusahakan secara masal, sedangkan jenis Mahoni dan Afrika masih dianggap sebagai kayu 'rawa' atau kurang dicari oleh pasar, dan tidak terlalu diusahakan secara masal.

\section{Analisis Kesesuaian dan Ketersediaan Lahan}

Kesesuaian lahan untuk tanaman preferensi diperoleh dengan membandingkan karakteristik lahan dan iklim dengan persyaratan tumbuh tanaman preferensi. Hasil analisis menunjukan luas wilayah yang sesuai untuk tanaman Sengon di Kabupaten Kuningan adalah 60,977 ha atau sebesar $51 \%$ dari luas wilayah (terdiri dari S1 21,669 ha dan S2 39,308 ha). Sesuai untuk Mahoni terdapat seluas 72,688 ha (61\%) (terdiri dari S1 415 ha, S2 15,021 ha, dan S3 57,252 ha). Kesesuaian lahan untuk Afrika seluas 79,192 ha (66\%), dan untuk Jati terdapat seluas 66,678 ha (56\%) (terdiri dari S1 3,728 ha, S2 23,597 ha, dan S3 39,353 ha).

Kemudian analisis ketersediaan lahan untuk pengembangan hutan rakyat berdasarkan penggunaan lahan tahun 2017 dan Pola Ruang RTRW Kabupaten Kuningan 2011-2031 menunjukan terdapat lahan potensial seluas 29,518 ha. Sebagian merupakan lahan yang diprioritaskan karena mempunyai fungsi ekologis dan juga rawan bencana alam. Luas lahan prioritas terdapat seluas 15,846 ha atau $13 \%$ dari luas wilayah.

Lahan prioritas diarahkan untuk Mahoni dan Afrika dengan pertimbangan kayunya kurang diminati sehingga akan jarang ditebang, 
sedangkan lahan bukan prioritas diarahkan untuk Sengon dan Jati karena kayunya banyak dibutuhkan dan akan sering terjadi penebangan.

Kelas kesesuaian dan urutan preferensi menjadi dasar dalam penentuan prioritas tanaman di masing-masing wilayah tersedia. Kelas kesesuaian yang lebih tinggi akan lebih diutamakan, jika kemudian hasil overlay menunjukkan kelas kesesuaian yang sama maka tanaman prioritas dilihat dari urutan nilai preferensi sesuai TOPSIS.

Hasilnya menunjukkan lahan yang berpotensi untuk pengembangan jenis Sengon adalah seluas 9,173 ha, Mahoni seluas 9,938 ha, Afrika seluas 858 ha, dan Jati seluas 2,040 ha. Perbandingan luas lahan sesuai dan yang tersedia bisa dilihat pada Gambar 4, sedangkan untuk sebarannya bisa dilihat pada Gambar 5.

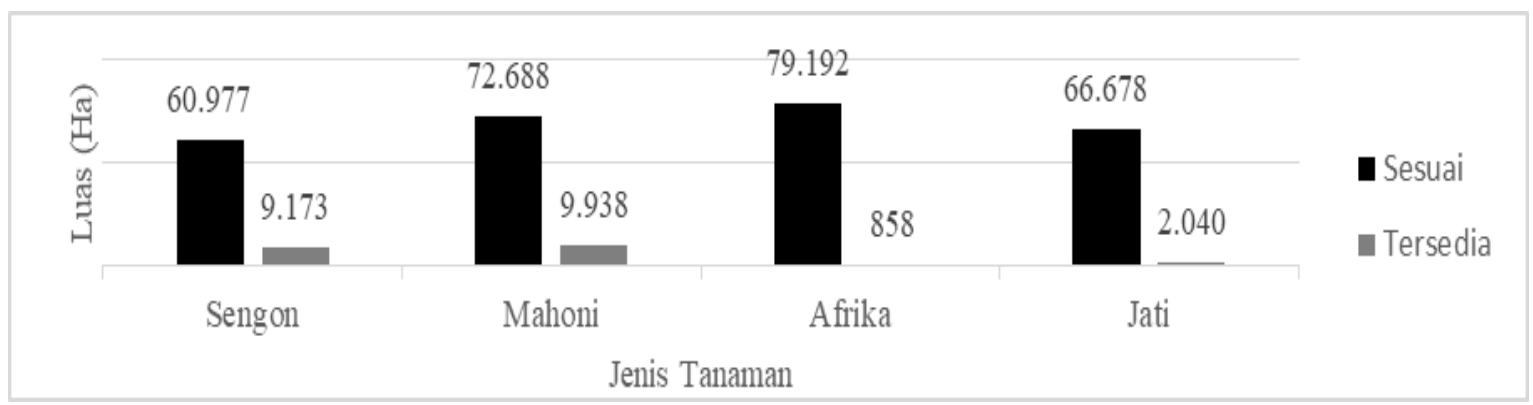

Gambar 4. Grafik perbandingan luas lahan sesuai dan lahan tersedia untuk tanaman preferensi dalam pengelolaan hutan rakyat di Kabupaten Kuningan tahun 2017

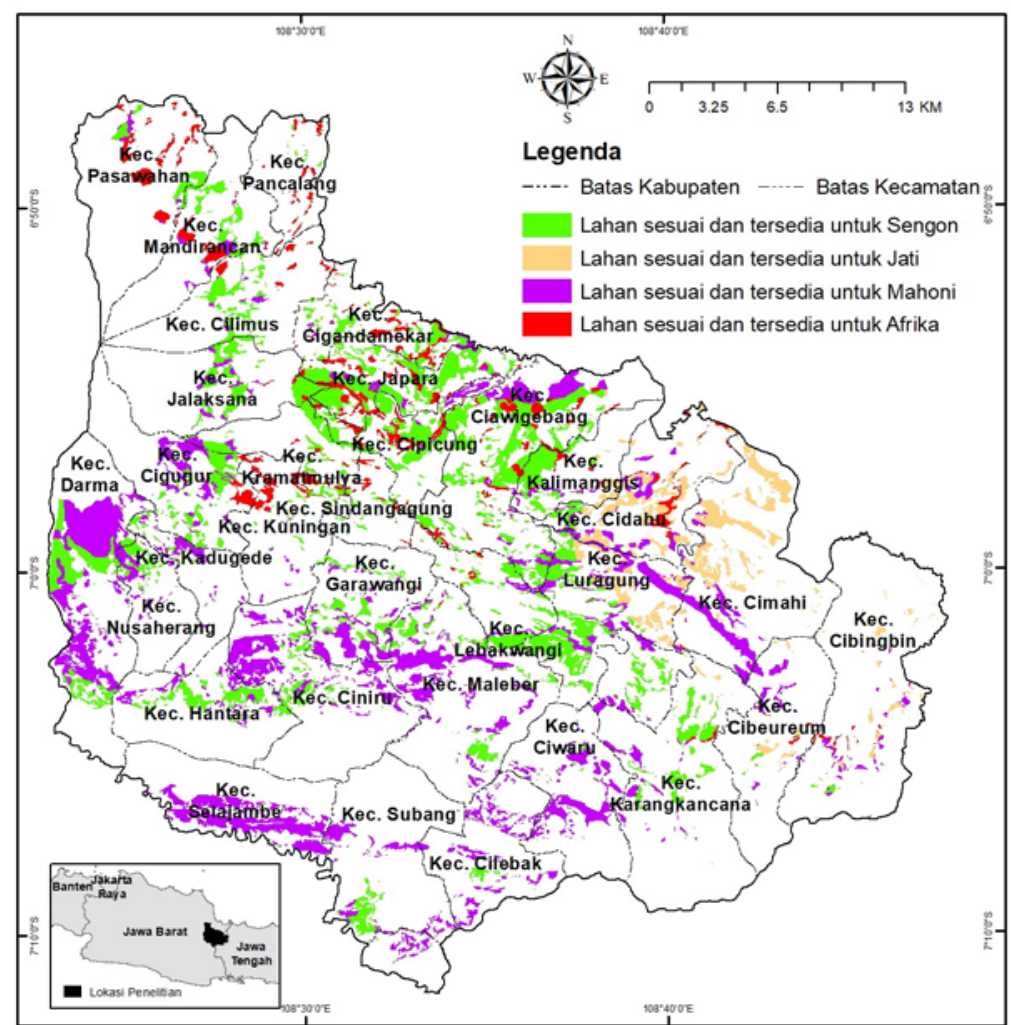

Gambar 5. Peta kesesuaian dan ketersediaan lahan untuk komoditas hutan rakyat di Kabupaten Kuningan

\section{Perwilayahan Komoditas Unggulan Hutan Rakyat}

Nilai Location Quotient (LQ) didasarkan atas analisis luas penggunaan lahan kering tahun 2016 dari BPS, yaitu Hutan Rakyat,
Kebun/Tegalan, Ladang/Huma, Kawasan Hutan, serta Lain-Lain. Terdapat 18 kecamatan dengan sektor basis pada hutan rakyat (nilai LQ hutan rakyat $>1$ ) yaitu Kecamatan Cipicung, Kuningan, Nusaherang, Japara, Kadugede, Kramatmulya, Subang, Luragung, Garawangi, 
Lebakwangi, Cigandamekar, Selajambe, Ciawigebang, Cilebak, Pancalang, Cimahi, Darma, dan Ciwaru.

Ini menandakan kegiatan pengembangan hutan rakyat merupakan sektor basis untuk Kabupaten Kuningan karena terdapat di lebih dari 50\% kecamatan. Hal ini didukung oleh hasil analisis Location Index (LI) yang juga menunjukan sektor hutan rakyat mempunyai nilai LI 0.22 atau mendekati 0, yang berarti kegiatan pengembangan hutan rakyat cenderung tersebar di wilayah Kabupaten Kuningan.

Shift Share Analysis (SSA) didasarkan atas luas pemanfaatan lahan kering dari BPS tahun 2011 dan 2016. Hasilnya menunjukan hanya hutan rakyat yang mempunyai nilai Proportional Shift (PS) tinggi yaitu 0.23, tipe lain bernilai negatif. Sebanyak 20 kecamatan atau lebih dari $50 \%$ mempunyai nilai
Differential Shift (DS) positif. Ini menunjukan bahwa sektor hutan rakyat merupakan aktifitas yang memiliki pengaruh penting terhadap pertumbuhan ekonomi di Kabupaten Kuningan.

Kombinasi antara nilai LQ $>1$ dengan nilai SSA khususnya DS $>0$, menunjukkan kecamatan yang mempunyai sektor unggulan pada hutan rakyat berjumlah 13, namun dengan pertimbangan bahwa Kecamatan Kuningan merupakan ibukota kabupaten dan sesuai RTRW lebih diarahkan sebagai permukiman perkotaan maka hanya 12 kecamatan yang layak dijadikan wilayah pengembangan hutan rakyat di Kabupaten Kuningan yaitu Kecamatan Ciawigebang, Cigandamekar, Cimahi, Cipicung, Ciwaru, Darma, Garawangi, Japara, Kramatmulya, Lebakwangi, Luragung, dan Nusaherang [Gambar 6].

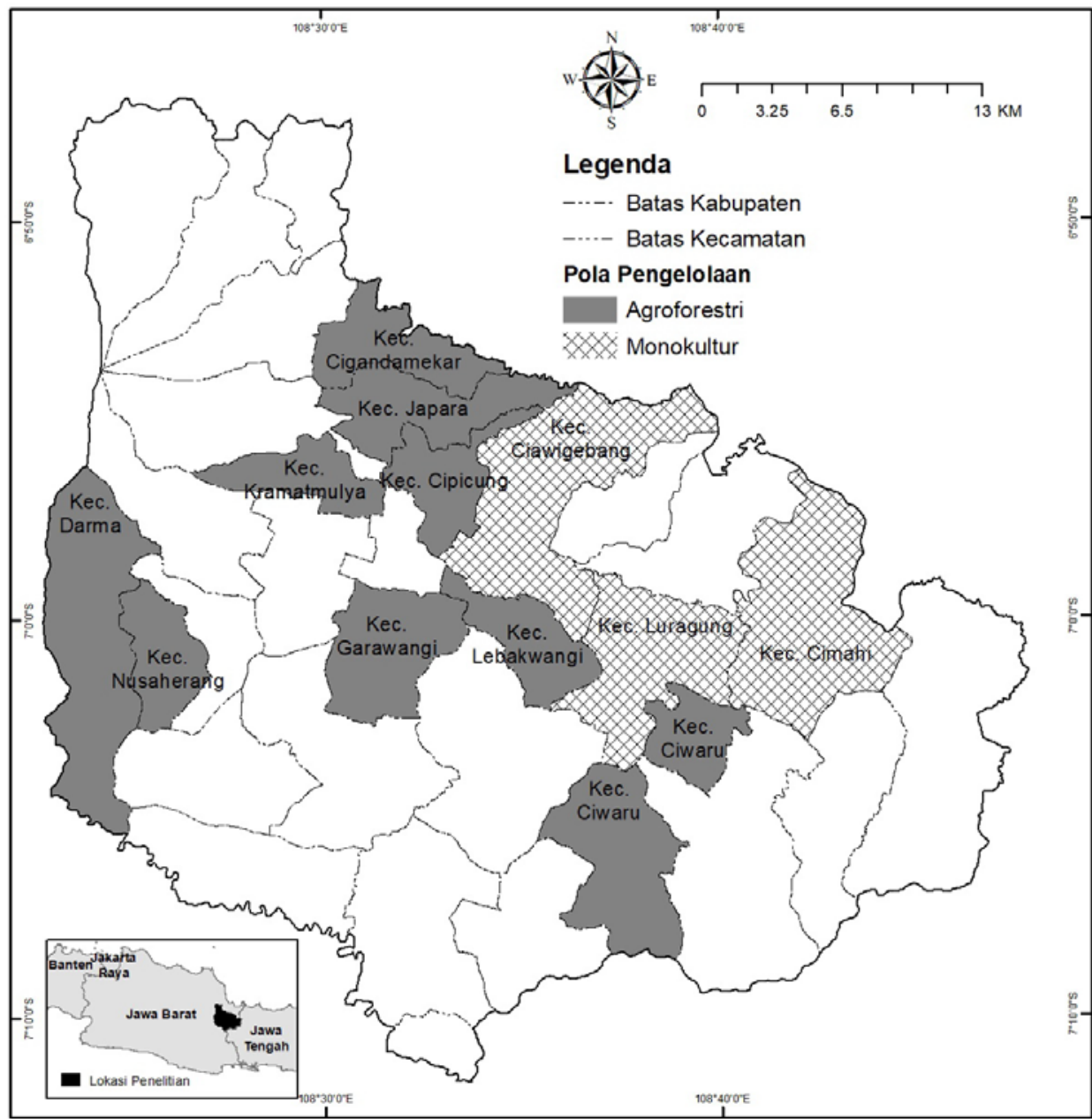

Gambar 6. Peta Arahan Wilayah Pengembangan Hutan Rakyat di Kabupaten Kuningan 


\section{Arahan Wilayah Pengembangan \\ Berdasarkan Komoditas Unggulan, Kesesuaian dan Ketersediaan Lahan}

Berdasarkan luas lahan sesuai dan tersedia pada kecamatan-kecamatan bernilai LQ > 1 dan DS > 0 (Gambar 6), serta mempertimbangkan karakteristik fisik wilayah, maka arahan jenis tanaman prioritas 1 di kecamatan-kecamatan wilayah tengah-utara dan timur adalah untuk Sengon dan Jati. Sedangkan di kecamatan-kecamatan wilayah barat dan selatan jenis tanaman prioritas 1 adalah Mahoni. Adapun untuk jenis prioritas 2 di setiap wilayah bervariasi seperti bisa dilihat pada Tabel 5.

Tabel 5. Arahan Wilayah Pengembangan Hutan Rakyat di Kabupaten Kuningan

\begin{tabular}{lllllll}
\hline No. & Kecamatan & Prioritas 1 & Prioritas 2 & Wilayah & $\begin{array}{l}\text { Penggunaan } \\
\text { Lahan Kering }\end{array}$ & Pola \\
\hline 1 & Ciawigebang* & Sengon & Mahoni & Timur & PR, Pk, SB, TL & MK \\
2 & Cigandamekar & Sengon & Afrika & Tengah / Utara & Pk, SB, TL & AGF \\
3 & Cimah* & Jati & Mahoni & Timur & PR, Pk, SB, TL & MK \\
4 & Cipicung* & Sengon & Afrika & Tengah / Utara & Pk, SB, TL & AGF \\
5 & Ciwaru* & Mahoni & Sengon & Selatan & PR, Pk, SB, TL & AGF \\
6 & Darma* & Mahoni & Sengon & Barat & PR, Pk, SB, TL & AGF \\
7 & Garawangi* & Mahoni & Sengon & Selatan & Pk, SB, TL & AGF \\
8 & Japara* & Sengon & Mahoni & Tengah / Utara & Pk, SB, TL & AGF \\
9 & Kramatmulya & Sengon & Mahoni & Tengah / Utara & Pk, SB, TL & AGF \\
10 & Lebakwangi & Sengon & Mahoni & Tengah / Utara & Pk, SB, TL & AGF \\
11 & Luragung* & Sengon & Jati & Timur & PR, Pk, SB, TL & MK \\
12 & Nusaherang & Mahoni & Sengon & Selatan & Pk, TL & AGF \\
\hline
\end{tabular}

Keterangan;

$*$ = luas sesuai dan tersedia $>500$ ha

PR (Padang Rumput), Pk (Perkebunan/Kebun), SB (Semak Belukar), TL (Tegalan / Ladang)

MK (Monokultur), AGF (Agroforestri)

Lokasi atau lahan yang bisa dijadikan areal pengembangan adalah pada penggunaan lahan kering seperti padang rumput, perkebunan (rakyat) / kebun, semak belukar, dan tegalan / ladang.

Untuk pola pengelolaan prioritas adalah agroforestri. Menurut Rizal et al. (2012) pola agroforestri adalah campuran komposisi tanaman jangka pendek berupa tanaman semusim, jangka menengah berupa tanaman sela, dan jangka panjang berupa tanaman kehutanan. Dengan menerapkan pola tersebut, pendapatan masyarakat dapat meningkat melalui perolehan hasil dari tanaman. Pola agroforestri direkomendasikan terutama untuk wilayah barat, tengah-utara, dan selatan. Sedangkan untuk wilayah bisa diusahakan secara monokultur. Pola agroforestri adalah sebuah langkah menuju peran yang lebih besar untuk berkontribusi dalam pembangunan pedesaan (Hani \& Suryanto, 2014).

Mengingat bahwa secara topografis di Kabupaten Kuningan banyak wilayah yang berlereng terjal dan rawan bencana gerakan tanah, maka dengan pola apapun jika hutan rakyat di lokasi tersebut, teknis pengelolaannya harus memperhatikan aspek-aspek konservasi. Misalnya melakukan sistem tebang pilih, segera melakukan penanaman kembali, pembuatan teras atau guludan, penanaman sejajar kontur, pengolahan tanah menurut kontur, penanaman penutup tanah, dan lain sebagainya.

\section{KESIMPULAN}

Berdasarkan minat masyarakat, komoditas kayu hutan rakyat yang berpotensi untuk dikembangkan di Kabupaten Kuningan adalah Sengon, Mahoni, Afrika, dan Jati. Semua komoditas layak diusahakan dengan pola pengelolaan yang disarankan adalah agroforestri untuk di wilayah barat, utaratengah, dan selatan, sedangkan di timur bisa dilakukan secara monokultur. 
Luas lahan sesuai dan tersedia berdasarkan penggunaan lahan dan RTRW untuk pengembangan hutan rakyat berturutturut adalah tipe Mahoni 9,938 ha, Sengon 9,173 ha, Jati 2,040 ha, dan Afrika 858 ha.

Wilayah dengan sektor unggulan pada hutan rakyat terdapat di dua belas kecamatan yaitu Ciawigebang, Cimahi, Luragung (wilayah timur), Cigandamekar, Cipicung, Japara, Lebakwangi (wilayah tengah-utara), Kramatmulya, Darma (wilayah barat), Ciwaru, Garawangi, Nusaherang (wilayah selatan).

Arahan wilayah pengembangan hutan rakyat berdasarkan jenis prioritas yaitu untuk jenis Sengon di wilayah timur dan tengah-utara, jenis Mahoni diprioritaskan untuk wilayah barat dan selatan, jenis Afrika diprioritaskan di wilayah tengah-utara, dan jenis Jati diprioritaskan di wilayah timur. Pola pengelolaan yang direkomendasikan adalah agroforestry, sementara di timur bisa dilakukan secara monokultur.

\section{UCAPAN TERIMAKASIH}

Penulis mengucapkan terimakasih kepada berbagai pihak yang telah mendukung berjalannya penelitian ini, yakni staf pengajar dari Program Magister Ilmu Perencanaan Wilayah (PWL) dan Departemen Ilmu Tanah dan Sumberdaya Lahan, Fakultas Pertanian IPB, serta Pusat Pengkajian Perencanaan dan Pengembangan Wilayah (P4W) - LPPM IPB.

\section{DAFTAR PUSTAKA}

Apriliana, F. (2012). Pengaruh Kombinasi Tebal dan Orientasi Sudut Lamina Terhadap Karakteristik Cross Laminated Timber Kayu Sengon (Paraserianthes falcataria L. Nielsen). Tesis. Institut Pertanian Bogor.
Apriyanto, D., Hardjanto, \& Hero Y. (2016). Peningkatan Peran Hutan Rakyat Dalam Mendukung Ketahanan Pangan Dan Penanggulangan Kemiskinan (Studi Kasus Di Kecamatan Nanggung, Kabupaten Bogor). Jurnal Silvikultur Tropika, 7 (3), 165-173.

[Bappeda Kuningan]. Badan Perencanaan dan Pembangunan Daerah Kabupaten Kuningan. (2012). Laporan Akhir Pengembangan Strategis Kabupaten Konservasi, Kabupaten Kuningan. Bappeda Kabupaten Kuningan.

Borza, S., Inta, M., Serbu, R., \& Marza, B. (2018). Multi-Criteria Analysis of Pollution Caused by Auto Traffic in a Geographical Area Limited to Applicability for an Eco-Economy Environment. Sustainability, 10 (11), 4240.

Buharman, Djam'an, D. F., Widyani, N., \& Sudrajat, S. (2011). Atlas Benih Tanaman Hutan Indonesia. Balai Penelitian Teknologi Perbenihan Tanaman Hutan Bogor.

[CIFOR]. Center for International Forestry Research, Pemerintah Kabupaten Malinau. (2007). Mewujudkan Kabupaten Malinau Sebagai Kabupaten Konservasi. www.cifor.org/publications /pdf_files/media/mediaback-groundmalinaukalpataru.pdf [July $10^{\text {th }} 2019$ ].

Cipta. S. W., Sitorus. S. R. P., Lubis, D. P. (2017). Pengembangan Komoditas Unggulan Di Wilayah Pengembangan Tumpang Kabupaten Malang. Jurnal Kawistara, 7 (2), 121-133.

Departemen Kehutanan Republik Indonesia. (1997). Surat Keputusan Menteri Kehutanan No.49/kpts-II/1997 tentang Pendanaan dan Usaha Hutan Rakyat. 
Departemen Kehutanan Republik Indonesia. (2013). Peraturan Menteri Kehutanan Republik Indonesia nomor P.9/MenhutII/2013 tentang Tata Cara Pelaksanaan, Kegiatan Pendukung dan Pemberian Insentif Kegiatan Rehabilitasi Hutan dan Lahan.

Diniyati, D., \& Achmad, B. (2015). Kontribusi Pendapatan Hasil Hutan Bukan Kayu Pada Usaha Hutan Rakyat Pola Agroforestri Di Kabupaten Tasikmalaya. Jurnal Ilmu Kehutanan, 9 (1), 23-31.

Dirgantara, U. (2008). Analisis Potensi Fisik, Sosial dan Ekonomi untuk Pengembangan Hutan Rakyat di Kabupaten Sukabumi. Tesis. Institut Pertanian Bogor.

[Dishut Jabar]. Dinas Kehutanan Provinsi Jawa Barat. (2018). Statistik Kehutanan Jawa Barat Tahun 2017. Dinas Kehutanan Provinsi Jawa Barat.

[FAO] Food and Agriculture Organization of the United Nations. (1976). A Framework for Land Evaluation. FAO Soils bulletin http://www.fao.org/3/x5310e/x5310e00. htm [April $5^{\text {th }}$ 2019].

Fatem, S. M., Awang, S. A., Maryudi, A., Pudyatmoko, S., Marwa, J., Manuhua, D., \& Lembang, S. (2019). Strategi Pembentukan Tambrauw Sebagai Kabupaten Konservasi di Papua. Jurnal Ilmu Lingkungan, 17 (2), 373-387.

Fatmawati, I., Fatmawati, \& Lestari, S. (2018). Kelayakan Finansial Agroindustri Kopi Lengkuas di Desa Matanair, Kecamatan Rubaru, Kabupaten Sumenep. Jurnal Agriekonomika, 7 (2), 176-187.

Foncha, J. N., \& Ewule, D. M. (2020). Community Forest Management: A Strategy for Rehabilitation, Conservation and Livelihood Sustainability: The Case of Mount Oku, Cameroon. Journal of Geoscience and Environment Protection, 8 (2), 1-14.
Hani, A., \& Suryanto, P. (2014). Dinamika Agroforestry Tegalan Di Perbukitan Menoreh, Kulon Progo, Daerah Istimewa Yogyakarta. Jurnal Penelitian Kehutanan Wallacea, 3 (2), 119-128.

Herwirawan, F. X., Kusmana, C., Suhendang, E., \& Widiatmaka. (2019). Kesesuaian Lahan Untuk Pengelolaan Hutan Rakyat Guna Pengentasan Kemiskinan Di Kawasan Perbatasan Kabupaten Timor Tengah Utara. Jurnal Pengelolaan Sumberdaya Alam dan Lingkungan, 9 (1), 29-39.

Ibrahim, A. N. (2017). Analisis Finansial Hutan Rakyat dan Pertanian Padi (Studi kasus: Desa Benda dan Desa Dukuhmaja, Kabupaten Kuningan, Jawa Barat). Tesis. Institut Pertanian Bogor.

Irawanti, S., Suka, A. P., \& Ekawati, S. (2012). Peranan Kayu Dan Hasil Bukan Kayu Dari Hutan Rakyat Pada Pemilikan Lahan Sempit: Kasus Kabupaten Pati. Jurnal Penelitian Sosial dan Ekonomi Kehutanan, 9 (3), 113-125.

Mindawati, N., \& Megawati. (2013). Manual Budidaya Mahoni (Swietenia macrophylla King.). Pusat Penelitian dan Pengembangan Peningkatan Produktivitas Hutan, Badan Penelitian dan Pengembangan Kehutanan, Departemen Kehutanan.

[NAS] National Academy of Sciece. (1983). Firewood Crops: Shrub and Tree Species for Energy Production Volume 2. National Academy Press.

Nuroniah, H. S., \& Putri, K. P. (2013). Manual Budidaya Sengon (Falcataria moluccana). Pusat Penelitian dan Pengembangan Peningkatan Produktivitas Hutan, Badan Penelitian dan Pengembangan Kehutanan, Departemen Kehutanan. 
Purnomo, E. N. S., Sihwi, S. W., \& Anggrainingsih, R. (2013). Analisis Perbandingan Menggunakan Metode AHP, TOPSIS, dan AHP-TOPSIS dalam Studi Kasus Sistem Pendukung Keputusan Penerimaan Siswa Program Akselerasi. Jurnal ITSMART, 2 (1), 1623.

Rismunandar, Kusmana, C., \& Syaufina, L. (2017). Strategi Kebijakan Pemanfaatan Jasa Lingkungan Air Secara Berkelanjutan di Taman Nasional Gunung Ciremai Kuningan-Jawa Barat. Jurnal Pengelolaan Sumberdaya Alam dan Lingkungan, 6 (2), 187-199.

Ritung, S., Nugroho, K., Mulyani, A., \& Suryani, E. (2011). Evaluasi Lahan Untuk Komoditas Pertanian. Balai Besar Penelitian dan Pengembangan Sumberdaya Lahan Pertanian, Badan Penelitian dan Pengembangan Pertanian.

Rizal, A., Nurhaedah, \& Hapsari, E. (2012). Kajian Strategi Optimalisasi Pemanfaatan Lahan Hutan Rakyat Di Provinsi Sulawesi Selatan. Jurnal Penelitian Sosial dan Ekonomi Kehutanan, 9 (4), 216-228.

Rochmayanto, Y., \& Supriadi, R. (2012). Skala Ekonomis Usaha Hutan Rakyat Kayu Pulp Di Kabupaten Kuantan Singingi Provinsi Riau. Jurnal Penelitian Sosial dan Ekonomi Kehutanan, 9 (2), 87-95.

Rustiadi, E., Saefulhakim, S., \& Panuju, D. R. (2009). Perencanaan dan Pengembangan Wilayah. Crestpent Press dan Yayasan Pustaka Obor Indonesia.

Setiawan, H., Barus, B., \& Suwardi. (2014). Analisis Potensi Pengembangan Hutan Rakyat Di Kabupaten Lombok Tengah. Majalah Ilmiah Globe, 16 (1), 69-76.
Supriatna, A. H. (2011). Pertumbuhan Tanaman Pokok Jati (Tectona grandis Linn F.) pada Hutan Rakyat di Kecamatan Conggeang, Kabupaten Sumedang. Tesis. Institut Pertanian Bogor.

Tagfira, Umar, S., \& Alam, A. S. (2018). Pendapatan Petani Pengusahaan Kayu Jati (Tectona Grandis) Di Desa Povelua Kecamatan Banawa Tengah Kabupaten Donggala. Jurnal Warta Rimba, 6 (3), 16.

Tarigan, R. (2005). Perencanaan Pembangunan Wilayah. Jakarta (ID): PT. Bumi Aksara.

Widarti, A. (2015). Kontribusi hutan rakyat untuk kelestarian lingkungan dan pendapatan. Prosiding Seminar Nasional Masyarakat Biodiversity Indonesia, 1 (7), 1622-1626.

Zaenuri, M. (2015). Analisis Strategi Pengembangan Sektor Pertanian Sub Sektor Bahan Pangan di Kabupaten Boyolali. Economics Development Analysis Journal, 4 (4), 385-396. 